\title{
DC Microgrid for Wind and Solar Power Integration
}

\author{
V. Jayalakshmi, K. Sakthivel, S. Sherine
}

\begin{abstract}
To help the coordination of wind and sun based power inside microgrids. An amassed form of sustainable breeze and sun quality age estimate is proposed to help the measurement of the operational save for day ahead of time and ongoing booking. At that point, a stoop control for power advanced converters identified with battery stockpiling is created and inspected. that is appeared to hold the balance of the microgrid's genuine time supply and call for. earlier undiscovered breeze and sun power are gathered on the rooftop and sides of a pinnacle, in this way supporting conveyance to electric autos on the floor. [19],[20],[21]

Keywords : Droop control, electric vehicle (EV), microgrid, multilevel energy storage, optimal scheduling, power electronic conversion, solar power, wind power
\end{abstract}

\section{INTRODUCTION}

The vitality framework proposed in this paper tries to manage the two issues identified with power and transportation divisions. One limit answer is a smaller scale matrix that might be vertically consolidated with an inordinate upward push working as much of the time experienced in city areas. The gathering of sustainable breeze and sun based vitality happens on the highest point of the structure. The housetop period associates with the ground level by means of a small scale lattice where electric vehicle (EV) charging stations are provided, and a battery aides safeguarding the parity of stock and call for.incorporated converter topology for interfacing among the quality stockpiling machine and the dc transport for a private microgridapplicationThe proposed $\mathrm{dc}-\mathrm{dc}$ converter, is the blending of a total extension and an ahead converter. complete-connect converter is responsible for the vitality stockpiling framework releasing stage, while the forward converter is obligated for the quality stockpiling contraption charging stage. This ahead converter resultant by utilizing the blend framework is known as a twofold finished forward converter.Figure 1:DC-DCbidirectional converter.

Revised Manuscript Received on August 22, 2019.

Dr.V.Jayalakshmi, Department of EEE,Bharath Institute of Higher education and research, Tamilnadu, India. Email: Jayalakshmiv.eee@gmail.com

K.Sakthivel, Department of EEE,Bharath Institute of Higher education and research, Tamilnadu, India. Email: ksakthivelme@gmail.com

S.Sherine, Department of EEE,Bharath Institute of Higher education and research, Tamilnadu, India. Email: nssherine@gmail.com

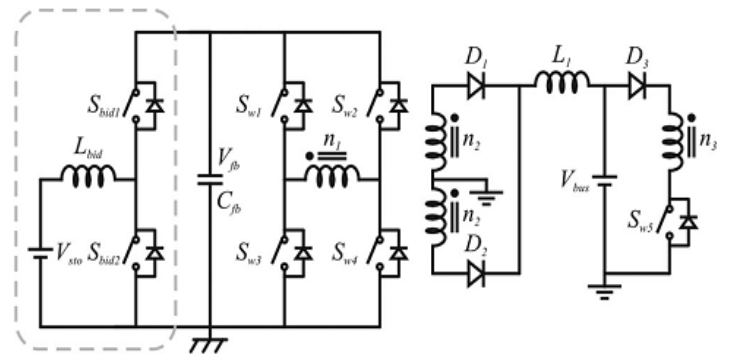

Fig. 1: Ciricuit diagram of an existing system

\section{PROPOSED SYSTEM}

Inside the principal stage, wind and sun power innovation are forecast,wind and sun power estimates are collected to deliver the generally speaking inexhaustible quality conjecture version. The totaled power innovation information are utilized to dole out hourly high caliber and awful vitality stores to the BESS for the microgridoperation. The BESS can handiest be charged and released inside the activity area in conventional activity mode, that is booked by optimization.in the interconnected method of activity, a versatile hunch oversee is conceived for the BESS[1],[3],[5]

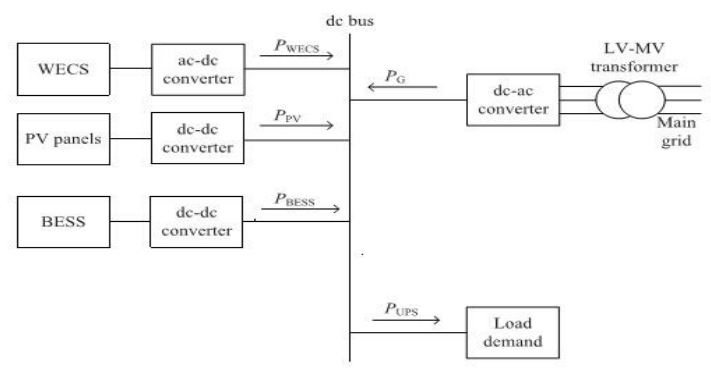

Figure 2: Block diagram of the proposed system.

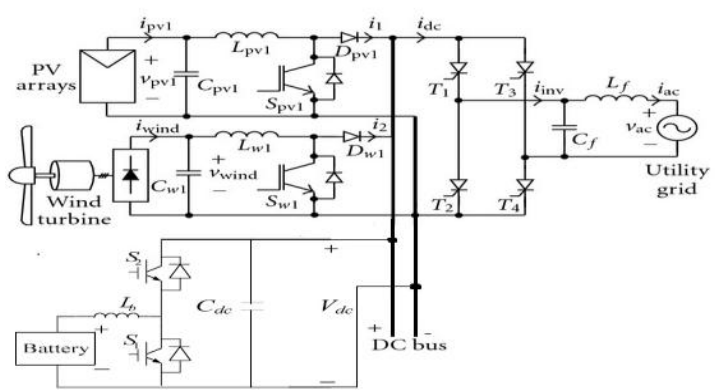

Figure 3: Circuit diagram of the proposed system. 


\section{PULSE WIDTH MODULATION (PWM) BASICS}

There are numerous kinds of regulation utilized for talking statistics. at the same time as a high recurrence sign has an abundancy one-of-a-kind in reaction to a decrease recurrence sign we've got AM (plentifulness tweak). at the same time as the signal recurrence is fluctuated in response to the adjusting signal we've FM recurrence stability. the ones alarms are utilized for radio tweak considering that the excessive[7],[9] ,[11]

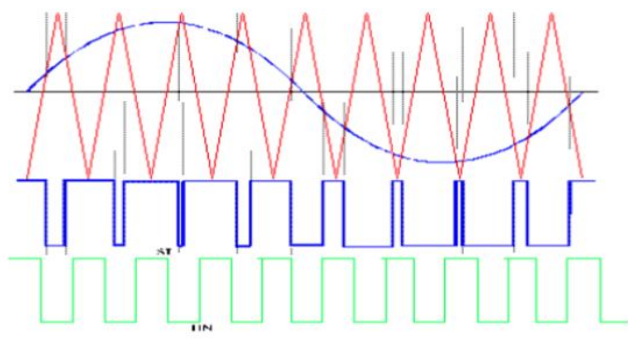

Figure 4: Unmodulated, sine modulated pulses

\section{LINEAR MODULATION}

The gain of direct dealing with for this product lies within the simplicity of de-tweak. The balancing signal is probably recuperated from the PWM by way of methods for low bypass sifting. For an single low recurrence sine wave as adjusting signal tweaking the width of a fixed recurrence (fs) beat train the spectra is as seemed in perceive under. [8],[10],[12]

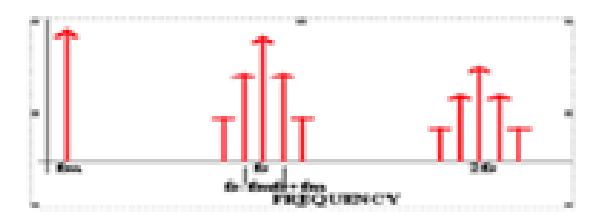

Figure 5: Spectra of PWM

\section{SAW TOOTH PWM}

the primary easy state of making constant recurrence PWM is via methods for assessment with a immediately incline waveform alongside a noticed tooth. As discovered in Fig2 the yield sign is going unnecessary whilst the sine wave is better than the saw lacquer. that is carried out the usage of a comparator whose yield voltage goes to a presence of thoughts excessive when info is extra than the opposite. [2 ], [ 4],[6]

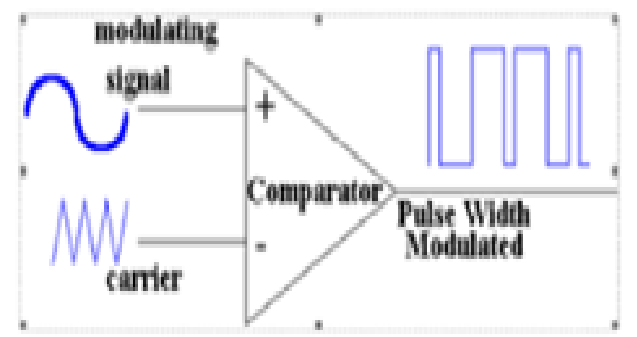

Figure 6: Sine tooth PWM

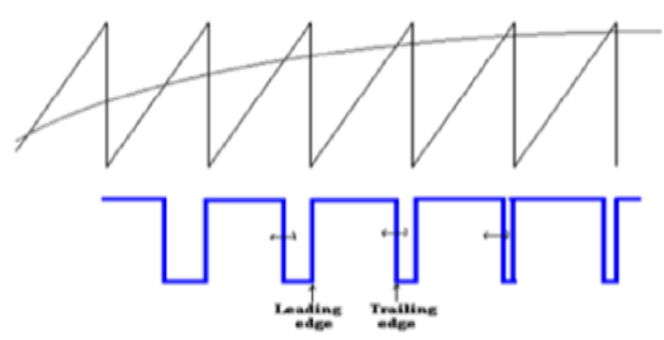

Figure 7: Trailing Edge Modulation

\section{V1. RESULTS}

Thus the circuit diagram is simulated and its results is obtained. The hardware model is manufactured.

The figure 9 below shows the voltage of the wind with respect to time and the current output with respect to time.

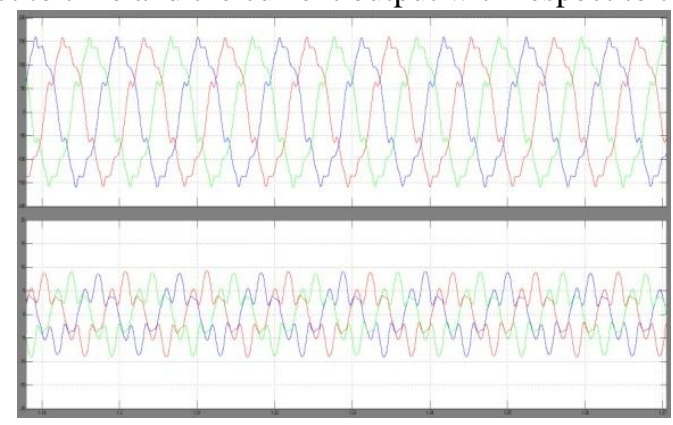

Figure 8:Wind voltage and current output

The figure 9 below shows the curve for battery state of charge i.e the charging and the discharging state. It also shows the output voltage and current. [13], [15], [ 17]

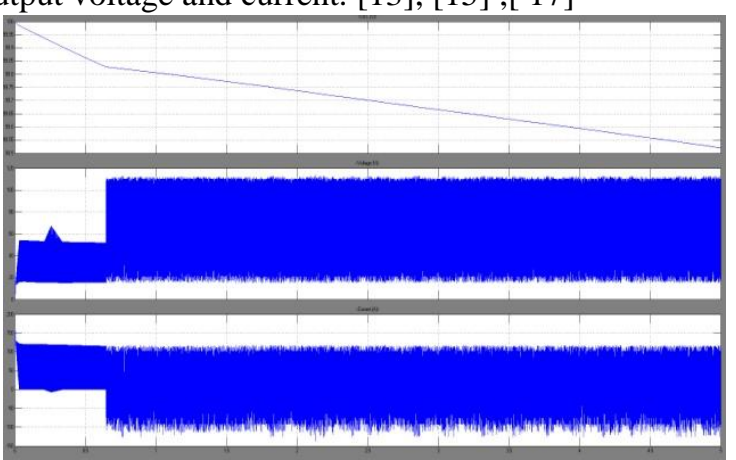

Figure 9:Battery SOC, voltage and current output.

The figure 10 below shows the grid voltage that varies with respect to current.

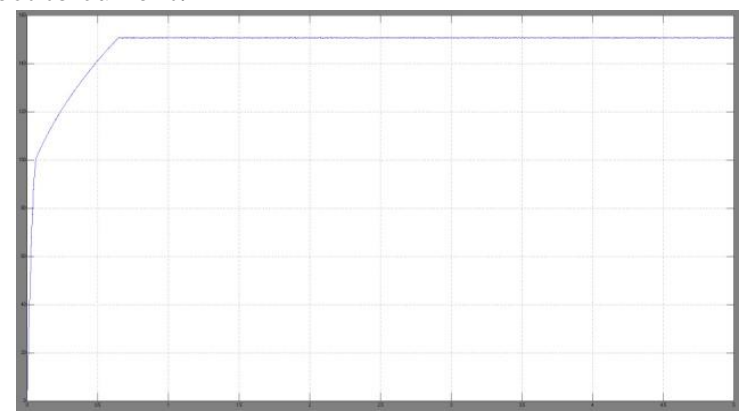

Figure 10: Grid voltage

Published By:

Blue Eyes Intelligence Engineering \& Sciences Publication 
The figure 11 shown below is the hardware prototype of a dc microgrid for wind and solar power integration. [14],[ 16], [18]

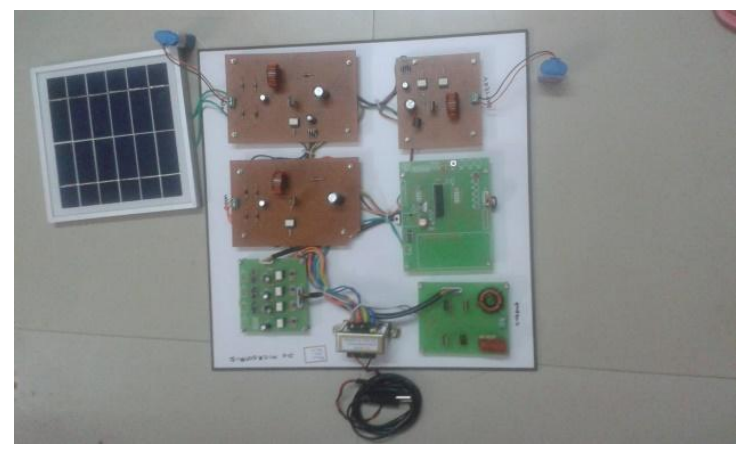

Figure 11: Hardware prototype

The figure 12 shown below is the output voltage waveform of the $\mathrm{dc}$ microgrid for wind and solar power integration. [19],[20],[21]

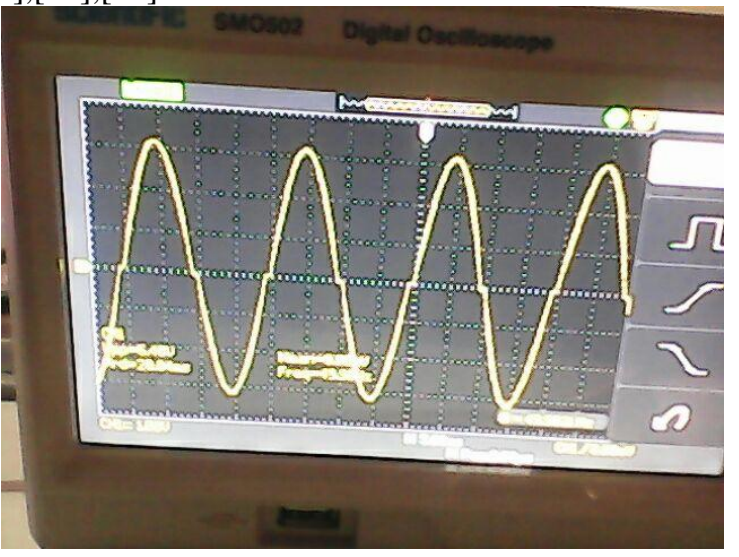

Figure 12: Output voltage waveform

\section{CONCLUSION}

A dc microgrid for sustainable power reconciliation has been proposed. The operational development and power gadgets essentially based totally voltage-nice stoop manipulate become developed, and the working changed into attempted by using exercise. collaboration with the standard framework transformed into controlled because of an operational enhancement that appears to limit expense and discharges. The manipulate proposed here is flexible in that the voltage-excellent hold bends are modified relying on the result of the operational improvement.

\section{REFERENCES}

[1] Sharma, R.K., Irusapparajan, G. \& Periyaazhagar, D. 2019 "Three-phase symmetric cascading Z-source seven levels multilevel inverter excited by multi carrier sinusoidal pulse width modulation scheme", International Journal of Innovative Technology and Exploring Engineering, vol. 8, no. 10, pp. 4269-4274

[2] Velavan, R., Bharanidharan, S. \& Sheeba, B. 2019, "EMF pollution Causes, effects and protection", International Journal of Innovative Technology and Exploring Engineering, vol. 8, no. 9 Special Issue 3, pp. 1166-1168.

[3] Saravana, S., Balaji, S., Arulselvi, S. \& John Paul Praveen, A. 2019 "Reliable power quality monitoring and protection system", International Journal of Innovative Technology and Exploring Engineering, vol. 8, no. 9 Special Issue 3, pp. 644-645.

[4] Tamil Selvan, S. \& Sundararajan, M. 2019, "Performance Parameters of 3 Value $8 \mathrm{t}$ Cntfet Based Sram Cell Design Using H-Spice", International Journal of Recent Technology and Engineering, vol. 8, no. 2 Special issue 5, pp. 22-27.
[5] Jac Fredo, A.R., Abilash, R.S., Femi, R., Mythili, A. \& Kumar, C.S 2019, "Classification of damages in composite images using Zernike moments and support vector machines", Composites Part B: Engineering, vol. 168, pp. 77-86.

[6] Kathiravan, P. \& Govindaraju, C. 2019, "Design and evaluation of ultra gain isolated DC-DC converter for photovoltaic system", International Journal of Engineering and Advanced Technology, vol. 8, no. 5, pp. 2646-2651.

[7] Kripa, N., Vasuki, R. \& Kishore Kanna, R. 2019, "Realtime neural interface controlled au-pair BIMA bot", International Journal of Recent Technology and Engineering, vol. 8, no. 1, pp. 992-994.

[8] Mohanraj, Meenaa Kumari, M., Philomina, S. \& Jasmin, M. 2019 "In-situ humidity measurement of hydrogen fuel cell car using MEMS sensor", International Journal of Recent Technology and Engineering, vol. 8, no. 1, pp. 41-43.

[9] Velmurugan, T. \& Prakash, S. 2019, "Artificial intelligent based distribution automation of swift fault detection isolation and power restoration for HT network", International Journal of Innovative Technology and Exploring Engineering, vol. 8, no. 6, pp. 1-6.

[10] Dwarakesh, K. \& Prem Kumar, G. 2019, "Five-level inverter based sequential boost system using fuzzy logic controller", International Journal of Innovative Technology and Exploring Engineering, vol. 8, no. 6, pp. 12-19.

[11] Anne Gifta, A. \& Hemavathi, G. 2019, "Analysis of grid tied solar Py system using ANFIS Algorithm", International Journal of Innovative Technology and Exploring Engineering, vol. 8, no. 6, pp. 312-316.

[12] Jayavel, R., Rangaswamy, T.R. \& Prakash, S. 2019, "Efficient grid management system with renewable and conventional power sources", International Journal of Innovative Technology and Exploring Engineering, vol. 8, no. 6, pp. 287-289.

[13] Hemavathi, G. \& Maheshwaran, S. 2019, "Proportional resonant controlled high gain step-up converter system with improved response", International Journal of Innovative Technology and Exploring Engineering, vol. 8, no. 6, pp. 317-323.

[14] Periyaazhagar, D. \& Irusapparajan, G. 2019, "Design and completion of asymmetric single phase 27 level cascaded mli for various pwm scheme", International Journal of Innovative Technology and Exploring Engineering, vol. 8, no. 6, pp. 792-797.

[15] Mahalakshmi, V. \& Vijayaragavan, S.P. 2019, "PV based power electronic converters for high voltage DC applications", International Journal of Recent Technology and Engineering, vol. 7, no. 6, pp. 670-674.

[16] Irusapparajan, G., Periyaazhagar, D., Prabaharan, N. \& Rini Ann Jerin, A. 2019, "Experimental verification of trinary DC source cascaded h-bridge multilevel inverter using unipolar pulse width modulation", Automatika, vol. 60, no. 1, pp. 19-27.

[17] Sangeetha, G., Sherine, S., Arputharaju, K. \& Prakash, S. 2019, "On Line Monitoring of Higher Rated Alternator using Automated Generator Capability Curve Administer", Proceedings of the IEEE International Conference on \&amp;quot;Recent Trends in Electrical, Control and Communication\&amp;quot;, RTECC 2018, pp. 176

[18] Bycil, V.J. \& Wiselin, M.C.J. 2019, "Modeling and analysis of vibration energy harvesting system using piezo stack", International Journal of Mechanical and Production Engineering Research and Development, vol. 9, no. Special Issue 1, pp. 523-533.

[19] Sripada, A., Warrier, A., Kapoor, A., Gaur, H. \& Hemalatha, B. 2018 "Dynamic lateral balance of humanoid robots on unstable surfaces", International Conference on Electrical, Electronics, Communication Computer Technologies and Optimization Techniques, ICEECCOT 2017, pp. 539.

[20] Srinivasan, S., Thirumalaivasan, K. \& Sivakumaran, T.S. 2018 , "Performance evaluation of double-output luo converters", Journal of Advanced Research in Dynamical and Control Systems, vol. 10, no. 10 Special Issue, pp. 870-878.

[21] Karthikayen, A. \& Selvakumar Raja, S. 2018, "A skellam distribution inspired trust factor-based selfish node detection technique in MANETs", Journal of Advanced Research in Dynamical and Control Systems, vol. 10, no. 13, pp. 940-949.

\section{AUTHORS PROFILE}

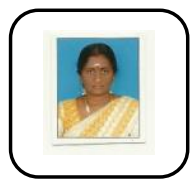

Dr.V.Jayalakshmi, Associate Professor Departmen of EEE,Bharath Institute of Higher education and research, Tamilnadu, India. 
DC Microgrid For Wind And Solar Power Integration

K.Sakthivel Assistant Professor Department of EEE,Bharath Institute of Higher education and research, Tamilnadu, India.

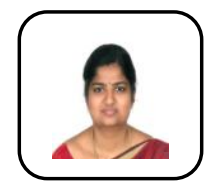

S.Sherine,Assistant Professor Department of EEE,Bharath Institute of Higher education and research,

Tamilnadu, India 